\title{
VISEGRÁD GROUP EXPERTISE AND POSITION IN THE SAMSUNG GLOBAL VALUE CHAIN: A CASE STUDY OF SAMSUNG ELECTRONICS IN THE V4 COUNTRIES
}

\author{
Endrődi-Kovács, V., Kutasi, G., Magasházi, A.
}

The participation of national V4 electronic industry in global value chains is a source of additional output, in addition to, a driver of technological development and employment. The aim of the study is to analyse whether the V4 region has the expertise capacity to upgrade its position in the electronics GVC integrated into the Samsung company. The analysis is built on the theory of GVC and the methodology of surveying the V4 labour market and education related to engineering. The quantitative results are supplemented with research interviews with Samsung managers and related municipal leaders. The analysis concludes on V4 upgrading opportunities in electronics GVCs determined by expertise.

Keywords: global value chain; global production networks; Samsung Electronics; Visegrad countries; innovation; expertise

JEL classification: $\mathrm{F} 23, \mathrm{O} 31, \mathrm{O} 32$

\section{Introduction}

National industrial enterprises within the transnationalized corporate networks are sources of additional output, drivers of technological development and employment, and can contribute extra income to the national economies. The electronics industry is one of the most important sectors which integrate V4 economies into Global Value Chains (GVC)/Global Production Networks (GPN). Samsung Electronics Co., Ltd. (SEC) was among the first companies which invested in Central and Eastern European (CEE) countries from the beginning of the 1990s. The paper analyzes the opportunities offered for the V4 economies to be integrated in the SEC global value chain in the past nearly three decades and discusses the different trajectories of the individual countries. SEC with its 169 subsidiaries world-wide is the flagship company of the Samsung Group, which ranked $6^{\text {th }}$ in 2017 in terms of brand value in the world. SEC has sales affiliates in 31 European countries, the volume of production, however, has undergone strong consolidation. The paper discusses whether the level of integration in SEC GVC has resulted in upgrading of local subsidiaries and suppliers in the electronics industry of V4 countries, and looks at what means state institutions in the V4 countries still possess to assist in plugging into the SEC Global Value Chain through activities with higher value added - such as R\& D and product design. Three topics are identified as factors important for a Korean company to extend its activity: expertise, state aid and market location.

The analyzed hypothesis is whether the V4 economies are stack into activities with lower value added in the global value chain because of limited expert capacities. The study focuses on the development of V4 expertise relevant for Samsung. Besides, based on this approach, it also attempts to answer such current questions like why only Poland has R\&D activity in the SEC GVC among the V4 countries or why SEC closes its factory in Slovakia. 


\section{Theoretical Background}

The extensive trade liberalization of trade and investment from the 1990s has led to the so called $2^{\text {nd }}$ unbundling of globalization as coined by Richard Baldwin (Baldwin, 2012), when not only the production has been separated geographically from the consumption through FDI, but a new organizational innovation has appeared in the development of transnational corporations (TNCs): the emergence of their global networks. TNCs are able to vertically fine-slice parts of their production processes with a punctuality that has never been seen before and settle them individually to optimal places according to competitive advantages (Buckley, 2009), matched to different profiles of countries with different development levels and professional experience. The competitiveness diamond model by Michael Porter determines the sources of competitive advantage as specialization in special skills or application of new materials, besides, becoming advanced and experienced in specific professional fields. The same basic skills, materials and capacities, or professionals with general knowledge have been given to many nations, which leads to parity and indifference instead of competitive advantage (Porter, 1990).

Around the Millennium, the research focus turned intensively towards the phenomenon of technological differentiation of the same production phases of a product, as well as the pre- and post-production stages of the value creation (Baldwin \& Evenett, 2012). Two distinct research frameworks have spun off from the globalization discipline: the analysis of Global Value Chains (GVCs) and of Global Production Networks (GPNs). The Global Value Chain analysis follows the different stages of the product from its "birth" till the end use, as value creation phases for the customer. It can be analyzed from the lead firm's governance perspective top down, but also bottom up, what share of the value added a particular stage of the value creation or a part of the production process contributes (Gereffy \& Fernandez-Stark, 2011). Typical stages of the value chain are: R\&D, product planning and design, production, marketing, distribution and after sales services. New input-output databases have been developed, financed by international institutions (WIOD, WTO/TiVA, UNCTAD/ Eora) to be able to track cross-border movement of intra-industry semi-finished goods and the level of value added produced. Baldwin and Evenett (2012) illustrated the different phases of the GVCs with the smile curve. The pre-production and post-production phases have a share of considerably higher value added in the total value of the product in the GVCs of the $21^{\text {st }}$ century than they had in the 1970s. The economics of smile curve points at the core observation, namely, that the 'value added along the value chain seemed to shift away from the offshored stages' (Baldwin, 2012, p. 37). In other words, the smile deepened, and this way it leaves less benefit to the countries contributing with low cost production activities in the value chain. These aspects have special importance in the analysis of the V4 electronics industry, as regards how and whether or not higher added value phases of production can be caught in the value chain.

Humphrey and Schmitz (2002) introduced a widely used typology of the economic upgrading:

1. Product upgrading: moving into more sophisticated products.

2. Process upgrading: introducing more advanced technology, organizational development in the production. 
3. Functional development: acquiring new, higher value-added functions in the chain (such as procurement, marketing, after sales services).

4. Inter-sectoral upgrading: capitalizing on the knowledge acquired in a value chain function expanding into another industry sector.

There are few and mixed empirical accounts in the literature as to whether subsidiaries have a possibility for upgrading, and if yes, whether it is originated in the development of V4 domestic suppliers. Pavlinek and Zizalova, whose study might be one of those which are based on the most extended data about the Czech automotive industry in the value chain, concluded that supplying into GVC does "not necessarily lead to the formation of strong linkages between foreign subsidiaries and domestic firms" (Pavlinek \& Zizalova, 2014, p. 5). On the other hand, Sass and Szalavetz (2012) found in their research that even though the country is linked through a production activity with less value added into the GVC, the production itself can be accompanied by development activities, as the physical location of the R\&D engineers may be required to be close to the location of the production.

The Global Production Networks (GPN) research framework is an in many respects similar, still distinct research framework, which also appeared around the beginning of the 2000s in the academic literature. It concentrates on the complex webs of production circuits and networks (Henderson et al., 2002). As Peter Dicken describes, individual production circuits are themselves enmeshed in inter- and intra-firm relationships. GPN scholars underline that in spite of the free movement of capital, and the deterritorialization of economic activity, "every component in a GPN - every firm, every economic function - is 'grounded' quite literally, in specific locations" (Dicken, 2015, p. 60). The nation state remains important as the location where GPNs can be embedded. States are not only regulators and actors, but they are also engaged with other major actors - labor, consumers, civil society. Equally vital is labor with the expertise it represents to GPN, which is far less mobile than the capital. "Labour is strongly differentiated geographically and deeply embedded in local communities" (Dicken, 2015, p. 62). The GPN theory tries to embrace all actors and relations holistically, however, it can measure impacts only with qualitative methods, through case studies, thus leading to conclusions mainly on a national level.

\section{Methodology}

The research period from 1990 to 2015 has been selected for the longitudinal research due to several factors: the start of the period coincides with the acceleration of globalization, the emergence of complex global production networks of TNCs, and, last but not least, Samsung's first CEE factory started its operation in Central and Eastern Europe in 1990. The study uses both qualitative and quantitative approach in the analysis.

\subsection{Qualitative Analysis}

The changing organizational system of TNC networks, locational strategies of the mother company, their interconnectedness with various actors in the host country environment and actions towards upgrading in the global value chains can best be analyzed by qualitative methods, such as personal interviews (Parilli, 2014; Yeung, 2016). The method of 
semi-structured interviews was selected for the research. In this interview form the basic structure is given, it, however, remains flexible enough to allow those contents to emerge as well which are not pre-planned, but belong to the wider frame of the topics of the interview. Eight interviews were conducted in Hungary in three phases in 2015, 2017 and 2018, expanding the scope in order to analyze the level of embeddedness of the Samsung GPN in Hungary, putting emphasis on expertise and the role of the state. Interview partners were the Samsung manager for Legal Affairs and Government Relations on two occasions, owners of two major local suppliers of Samsung, the director of a technical secondary school of the micro region, the mayor of Jászfényszaru (already in office at the time of the investment), the director of the Jászfényszaru Industrial Park where Samsung is located, the manager of the Korean desk in the Ministry of Foreign Trade and Affairs, and the manager of KOTRA (Korea Trade-Investment Promotion Agency) representative office in Hungary. Three consultations with Korean experts from the academic sphere were carried out to fine tune the concept.

The following interviews and consultations were accomplished:

- Interview with Mr. Tibor Mezei, Head of Korean Desk in the Hungarian Ministry of Foreign Trade and Affairs on $24^{\text {th }}$ April 2015, SEC Hungary, Jászfényszaru.

- Interview with Dr. Péter Paróczi, Legal Councel, Samsung Electronics, Chief Compliance and Government Relations, on $30^{\text {th }}$ April 2015, SEC Hungary, Jászfényszaru.

- Interview with Ms. Yang, Kotra, Korean Trade and Investment Agency, Budapest Office, on $18^{\text {th }}$ May 2015.

- Interview with Mr. Lajos Kasza, owner and managing director of Jászplasztik Ltd., supplier of SEC Hungary, on $17^{\text {th }}$ January 2017, Jászberény.

- Interview with Mr. Tibor Birgés, managing director of Ferro-Press Ltd., supplier of SEC Hungary, on $17^{\text {th }}$ January 2017, Jászberény.

- Consultation with Korean national experts: 1. Seok-Joon Choi, Ph.D - University of Seoul, professor at Department of Economics; 2. Yong-Seok Choi, Ph.D. - Kyung Hee University, professor at College of Politics and Economics, Department of Economics; 3. Myungsoo Park, Ph.D. in Economics; on $17^{\text {th }}$ January 2017, Budapest.

- Consultation with Ms. Győriné dr. Czeglédi Márta, mayor of Jászfényszaru since 1990, on $23^{\text {rd }}$ March 2018.

- Interview with Mr. László Versegi, managing director of the Jászfényszaru Industrial Park (JIC), on $23^{\text {rd }}$ March 2018.

- Consultation with László Szabó, József Liska Secondary School, Jászberényon 23 ${ }^{\text {rd }}$ March 2018.

\subsection{Quantitative Analysis}

For the exploratory/comparative statistical analyses to track the role of expertise, international (OECD) and national statistics have been accessed. The development of home country's and host countries' semi-finished goods trade interactions were analyzed with the help of the World Input-Output Database (WIOD) - financed by the EU. The last extension of the database was published in 2016, adding data from 2014 as well. Data and 
information was gained furthermore from primary government reports from the Hungarian government portal and portals reinforcing government information (sikerado.hu 2012-2018) on Samsung's global and Hungarian activities, interactions with the government, as well as from secondary sources.

Based on consultations with Korean experts and on Porter's competitiveness diamond, three factors turned out to be important in improving the presence in the global value chains of a Korean company: expertise, state aid and market location.

It is widely common that investment in human capital and education impacts the productivity of workers, thus it has an effect on the competitiveness of a company (see e.g. Trapp, 2016 or Griliches, 2000). Companies prefer workers with higher education. Therefore, in regard to expertise, first we examine the share of people below upper secondary education, then the percentage of people (between age 25 and 64) who have attained upper secondary, post-secondary, non-tertiary or tertiary education. Since Samsung Electronics operates in electronics, for the company it is very important that its employees have the necessary knowledge about the industry. Technical knowledge is crucial for the company. Since the availability of data is scarce, we have chosen to measure this by the number of freshmen in higher education and their share in technical higher education institutions. The Republic of Korea puts great emphasis on education and the quality of education (Rodrik, 1997; Lee, 2002). The Republic of Korea spends a lot on tertiary education and the studentteacher ratio is low in order to increase the quality of education (OECD, 2017). On account of this, education is important for Samsung as well. To measure the quality of education, we used three main indicators: spending on tertiary education (\% of GDP), student-teacher ratio in tertiary education, and the latest PISA results. We compared the data with the corresponding figures of Korea and of potential rival countries.

Beyond education, the short-term situation of the labor market determines more directly the current supply of experts. To determine the labor reserves, the following employment indicators from the Eurostat are analyzed:

- Unemployment and employment ratio in the age group 15-64,

- Employment ratio of population with secondary, upper-secondary and tertiary education in the age group 15-64,

- Inactive population with upper secondary, post-secondary and tertiary education and ratio of overall inactive population willing to work in the age group 15-64.

Besides, to demonstrate the international factor and the qualitative limit, the statistical analysis is extended to the international wage differences, the net migration and the total factor productivity (TFP). These indicators are useful to conclude about the future perspectives.

\section{State of Integration of V4 Electronics in Samsung GVC}

\subsection{Samsung's Strategy on Internationalization and Innovation}

Samsung Electronics Co., Ltd. was $18^{\text {th }}$ on the Forbes Global 2000 List with a market cap of 161.6 billion dollars in May 2016. It realized 177.29 billion dollars sales and employed 235,999 people globally. It is engaged in the manufacturing and sales of electronic products (Forbes, 2017). 
One important pillar of the South Korean economic development has been the internationalization of the companies since the eighties. A major business paradigm shift towards internationalization came about in the history of Samsung in 1987, when Lee Kun-Hee took over as Chairman of the Group after five decades of rule from his father, who founded the company in 1938. Samsung Electronics has entered into the global market in three main phases. In the 1980s, it made green and brown field investments in locations with low labor cost such as Portugal or Hungary. SEC also built huge Research and Development Centers abroad, e.g. in New York, Tokyo, England or Texas. In 1996, Chairman Lee Kun-Hee identified the brand of Samsung as a low level brand, which must be upgraded, at least, to high quality brand, including fundamental innovation. Samsung has a hybrid management system, which mixes Japanese and American management practices. As a result, its innovation strategy contains elements of both Japanese and American innovation strategies, so its focus is on continuous improvement and applied R\&D, moreover, on innovation, marketing and design (Business Insider, 2013; Jung, 2014).

Since 2000, the South-Korean chaebol has launched partnerships and joint ventures to reach more countries and enter into these countries in a more effective way (e.g. with Sony in the case of LCD screens), concentrating on final consumer products. The main objective has been to be a quick second entrant in the market rather than to be the first mover. It copies marketing communication, product attributes as well as product design. SEC has an undeniable competitive advantage by using transfer of knowledge between its activities and adapting its products. Its main goal is to satisfy consumers' needs, but at a lower price (Simonin, 2014).

SEC exploits economies of scale with standardized products. The company usually sells its products in every market without local variations to fit most of the national markets. Therefore it works usually with global companies which sell standardized electronic products. SEC chooses countries with cheap, but well-qualified workforce, favorable legislation and business environment from where they reach relevant markets (Simonin, 2014).

\subsection{Samsung's Operation in V4 Countries}

In the V4 region, SEC is one of the most important electronics company. It has manufacturing plants in Hungary, Slovakia and Poland (in Jászfényszaru, Galanta, Voderady and Wronki), a Research and Development Center established in 2000 in Warsaw and an audio-visual equipment supplier sales unit for Czech Republic and Slovakia in Prague (Figure 1). The company has kept on expanding its capacities in the V4 region (Euromonitor International, 2011).

All V4 subsidiaries are governed by the head office in South-Korea according to the interview, in spite of the fact that their first V4 subsidiary, SEC Hungary, technically owns $50 \%$ of SEC Slovakia and the Czech sales subsidiary.

The impact of the expanding Samsung activity can be observed in the intra-industry trade relations between South-Korea and the V4 countries, especially Hungary and Slovakia. The interview partner in KOTRA Hungary estimated that $70 \%$ of the annual South-Korean exports turnover to Hungary was generated by the needs of SEC Hungary in 2015 (Magasházi et al., 2015, p. 27). 


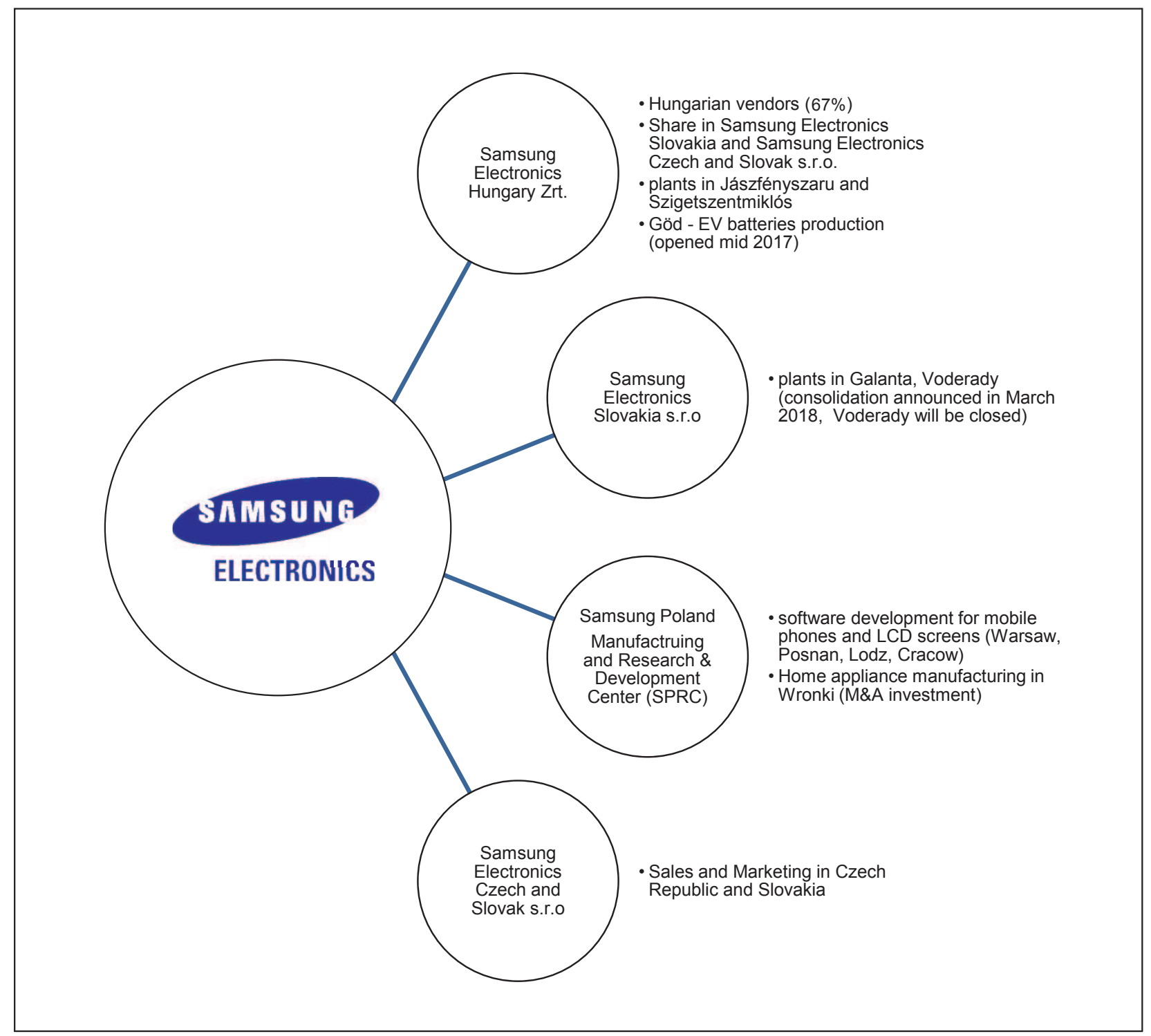

Source: authors' construction based on the interviews and on the literature

Besides the growth of the Korea-V4 intra-industry trade flow, it has substantially increased between the V4 countries as well, especially in the electronics segment and between Hungary and Slovakia, after the Slovakian factories also started their operations in 2002 and 2006 (WIOD database).

As a result of its global production network (GPN) framework, its territorial and actor network concept, the presence of Samsung Electronics in the V4 countries has led to an intensifying web in the triangle of state-state, state-firm and firm-firm relationships (Dicken, P. 2015).

Korea-V4 countries relationship: In the analyzed period, starting with building bilateral diplomatic relationships in 1989-1990 from scratch with each country individually, as well as signing Investment Protection Agreements, it has moved since 2013 towards the preparation of a V4+ format cooperation initiated by Korea, according to the interviews in the Ministry. The first V4-Korea summit took place in 2017 in Prague, where 
important steps were decided to foster scientific cooperation. The extension of Korea's Knowledge Sharing Program to the V4 region was decided and the event in spring 2018 is under preparation. The Korean party presented its proposal for R\&D cooperation: the V4-Korea Joint Research Program on Scientific and Technological Cooperation. Both initiatives from the Korean partner underline their long-term commitment towards the region in activities with higher value added. It can be a strong positive sign towards the Korean conglomerates.

\section{Figure 2 | Korean electrical and optical intra-industry exports to V4, million USD, current prices}

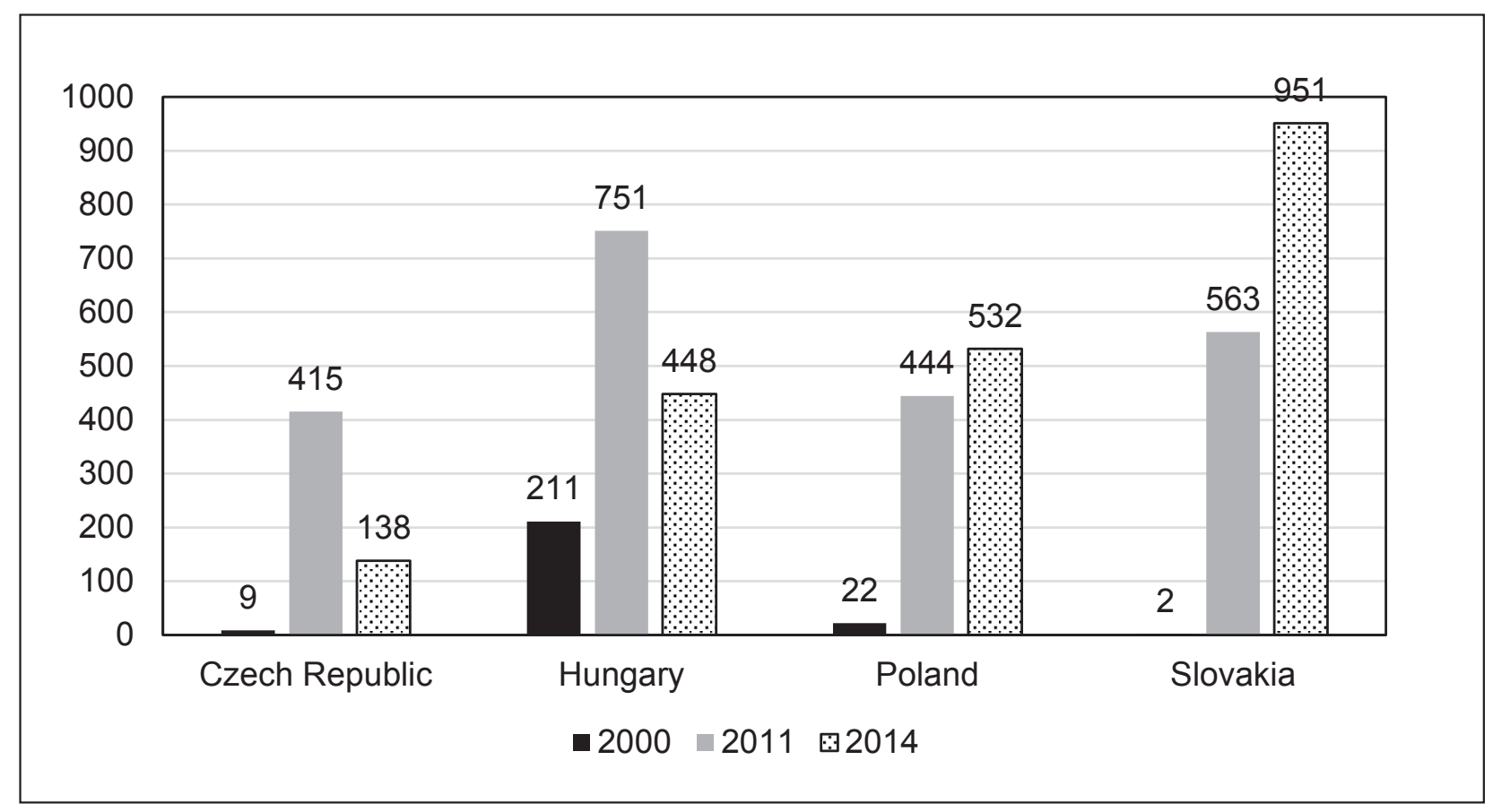

Source: authors' calculations based on latest WIOD release (2016)

State-firm relationship: In the case study, the interview partners both from Samsung and the public sphere - mayor, director of the Jászfényszaru Industrial Park where Samsung is located, director of Secondary School for Engineering, Jászberény - have confirmed long-term cooperative relationship among the actors. A supportive ecosystem has been created, grants and tax allowances are provided for technological upgrading and new investments. The interview partners from the local public institutions are making conscious efforts to develop towards a Triple-Helix cooperation.

Firm-firm relationship: In the case of the manufacturing facilities of Jászfényszaru and Galanta a successful advancement of supplier contacts can be observed. The two Hungarian suppliers, interviewed in 2017 in the neighboring town of Jászberény, Jászplasztik and Ferro-Press are SEC Hungary's major suppliers not only in Hungary. From a simple plastic spare-parts supplier Jászplasztik has evolved into a complex product supplier. Since 1998 their engineers have been involved in product and process development, when new products are introduced. Today 80 Jászplasztik engineers are taking part in the collaboration with Samsung in development processes, also working in cooperation with the Department of Material-technology of the Technical University in Budapest 
(Jászplasztik interview). Since 2005 Jászplasztik has moved into OEM position as well, assembling in 2010 as many as 2.5 million monitors for Samsung.

In 2000 Jászplasztik started manufacturing in Slovakia, initiated by their other major customer, Sony, Slovakia, to avoid import duties on the supplied parts. One year later, when Samsung embarked on location search in Slovakia, they invited the delegation to include Galanta as well as a possible location target. Today they are neighbors. Jászplasztik has 2200 employees in Galanta, almost as many as Samsung. In 2010 Jászplasztik and Ferro-Press were invited by Samsung Electronics to open factories in the Romanian village of Madaras, to supply their facility in close proximity. Jászplasztik, which was a small start-up in 1989, today has more than 3000 employees, 2200 in Slovakia and 450 in Romania, and has become a large transnational company itself parallel to the development of the Samsung subsidiaries with impressive upgrading trajectory. The company recorded 345 MEUR consolidated turnover in its 2015 balance sheet, out of which $40 \%$ was realized abroad, one third of its turnover was supplied to Samsung. It ranks $9^{\text {th }}$ among non-bank multinationals headquartered in Hungary (ICEG-CC, 2015). In their main site in Hungary, Jászplasztik relies on foreign workers as well, 10\% of whom are coming from Serbia, Romania and Ukraine.

The other important local supplier which started the production of metal parts in 2002 with 3 employees, the Ferro-Press in Jászberény, won the best supplier of SEC Hungary award in 2012. Ferro-Press had 77.5 MEUR turnover in 2015 on a factory area of $40.000 \mathrm{~m}^{2}$, and supplies today to $30 \mathrm{TNCs}$. "At the start we supplied a piece of spare part based on an exact technical drawing. At the end of 2016 we are designing the new product introductions for 2020 together with our clients. We have employees, who came to us from the university cathedra to support our development work" - explains the managing director of Ferro-Press. The Korean Sangjin Micro with 100 employees built its new factory in the Jászfényszaru Industrial Park in 2014 and supplies metal spare parts to the large factory. The share of Hungarian suppliers in 2015 amounted to 2/3, another $15 \%$ were suppliers from Korea and around 10\% from Slovakia (Samsung interview). All the three sets of relations support the assumption that SEC is strongly embedded in Hungary and in the V4 region.

In spite of the leading role of Hungary and Slovakia in the television production of Samsung, none of them have been awarded the function of R\&D. Engineers employed in the factories are involved in the process optimization when new products are introduced. (In SEC Hungary 100 persons out of 3600 employed.) Five to six persons are always dealing only with small innovations. The internationalization of SEC R\&D activity is in line with global trends. New centers have been launched in the USA, Japan, UK, Israel, China and India, as well as in Moscow (Samsung, 2017). Out of the V4 countries, only Poland managed to join the network of SEC R\&D centers in 2000, however, not with R\&D in the beginning of the value chain at the birth of new TVs, or household appliances manufactured in the region, but related to incremental product development services through IT engineering for new products. In the Polish R\&D Institute of Samsung Electronics, a diverse team of experts works in the areas of human language technology, computer vision, big data, Internet of Things, with the aim to design and implement innovative solutions for future Samsung products (Samsung R\&D Institute, Poland website). The attraction of the IT and network engineering, IT application development niche were also realized by Google, when it opened an R\&D unit in 2006 in Warsaw, or when the 
Microsoft Innovation Center in Poznan was established next to the Poznan Supercomputing and Networking Center in the emerging technological ecosystem. The Polish R\&D Center was extended from Warsaw to three other cities during the period of 2011 and 2013: Poznan, Cracow and Lodz. They are in close cooperation with local universities in the field of digital TV and smart phone programming, collaborating in the development of the curriculum. It has become Samsung's most import R\&D unit in Europe, relying on the strong mathematics education tradition as background (Tchorek, 2011). 'Poland's PISA scores are now above the OECD average and at the same levels as in countries such as Finland and Germany,' thanks to a set of reforms implemented in the education since early nineties with accelerated efforts from 2000 (World Bank, 2017).

\section{How Can V4 Countries Improve the Integration of their Electronics Industry into Samsung GVC?}

As mentioned above, three factors have significance in order to enhance the presence in the global value chains of a Korean company: expertise, state aid and market location. It can be briefly established, that the market locations of V4 countries are very favorable; these countries are in close proximity and have an easy access to the Western European markets, which are one of the main targets of Samsung Electronics. Using EU subsidies, these countries are continuously developing their infrastructure to make better access to Western markets.

Since V4 countries became EU member states, the provision of state aid has been strictly controlled by the EU. However, state aid is very important in the strategic decisions and R\&D activity of South-Korean companies, including Samsung Electronics (WTEC, 1997; Schlossstein, 2010). The risk-averse characteristic of South-Korean companies raises the importance of state aid in investment decisions. It can be observed in the decisions of Samsung Electronics as well. Through subsidies, risks can be shared; subsidies can reduce the possible losses and/or can be meant as guarantees of success. In addition, it can be observed, too, that within the V4 countries there is an intensive competition in the favorability of business environment to attract more investment into the country.

In the following, we are going to analyze the expertise factor in the context of V4 countries.

\subsection{Expertise}

While manufacturing plants operate in Hungary and Slovakia, Poland participates in the Samsung GVCs at a higher level, with R\&D as well. Other than the availability and cost of labor, expertise plays a key role in the decisions of SEC. Reviewing the SEC innovation strategy, it can be concluded that continuous innovation is a crucial activity in the company's life. It is also related to the manufacturing, for the sake of cost saving and process improvement. Thus, well qualified experts and engineers are very important. 


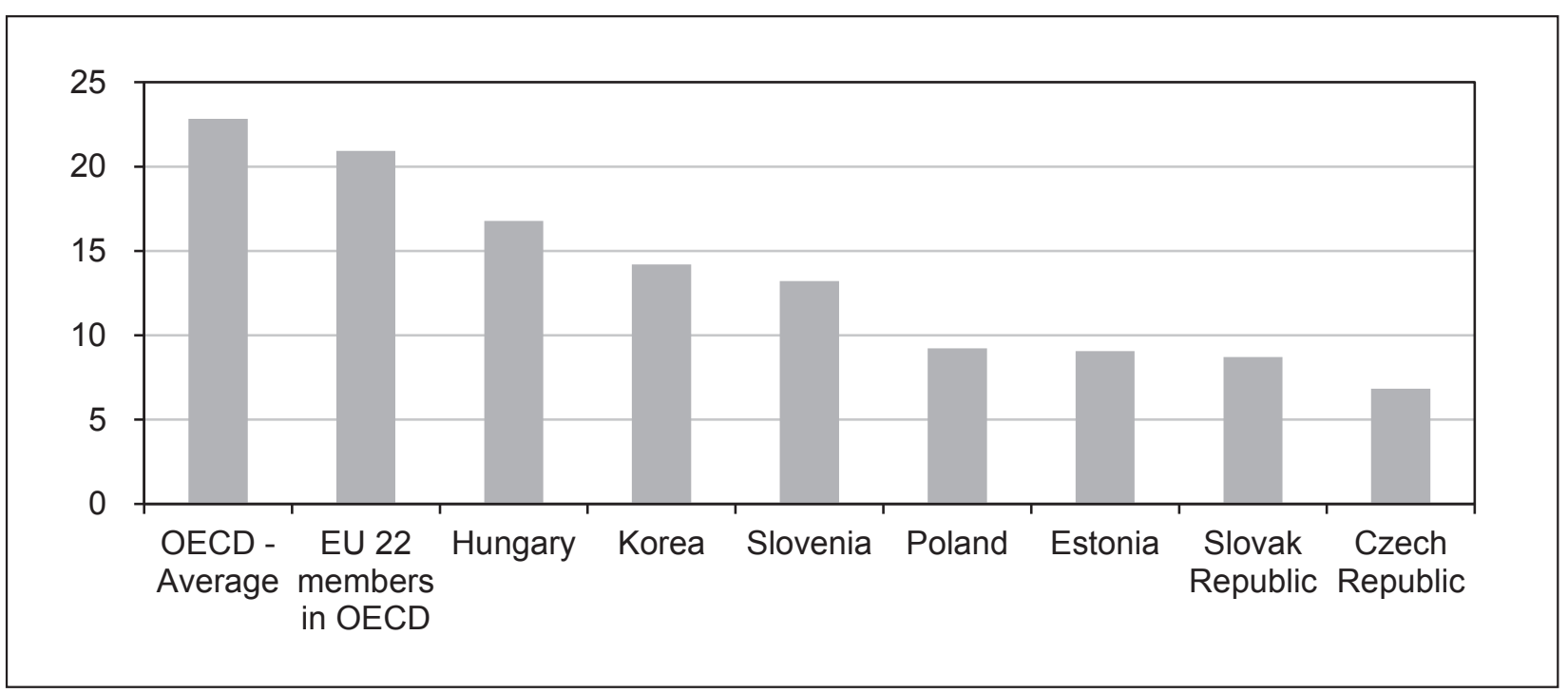

Source: authors, based on OECD Database (2017a)

As it is represented in Figure 3, there is a significantly higher ratio of people (between the age of 25 and 64) below upper-secondary education in V4 countries than the average of OECD and EU 22 in OECD. Moreover, the ratio is much lower than in the potential Asian rivals. Among V4 countries, Hungary performs the worst: 17\% of the Hungarian citizens have not attained secondary education, while this rate is under $10 \%$ in the other V4 countries.

The percentage of people (between age 25 and 64) who have attained upper secondary, post-secondary non-tertiary or tertiary education is higher in Hungary, Czech Republic, Poland and Slovakia than the OECD and EU 22 average. Among V4 countries, Hungary is the worst performing again. In Hungary, 5\% less people have attained upper, post-secondary or tertiary education than in the other V4 countries, although the Hungarian rate is 7 to $9 \%$ higher than the OECD and EU22 average, respectively. (See Figure 4) More than one-fifth of Polish, Hungarian, Czech and Slovakian residents have attained tertiary education, but these rates are lagging behind the OECD and EU 22 average and that of Korea (OECD, 2017b).

There are numerous tertiary education institutions in V4 countries with engineering faculties which are needed to improve the V4 position in SEC GVC. The number of freshmen in technical universities in Slovakia, Hungary and Poland has decreased in the recent years. (See Figure 5) In 2015, 25\% less freshmen entered the technical higher education institutions in Slovakia, 20\% less in Poland and 10\% less in Hungary than in 2008. (In case of Czech Republic, a proxy indicator had to be used because of absence of data, the share of students graduated in sciences. This indicator stagnates.)

This is in line with the general decrease of the number of applicants to higher educational institutions. It is explained by demographic changes: the V4 population between the age of 19 and 24 has been decreasing year-by-year (Central Statistical Office of Poland, 2015; Eduline, 2013). Another explanation might be that students choose studying in other European countries. 
Figure 4 | Percentage of people (between age 25 and 64) with upper, post-secondary and tertiary educational attainment

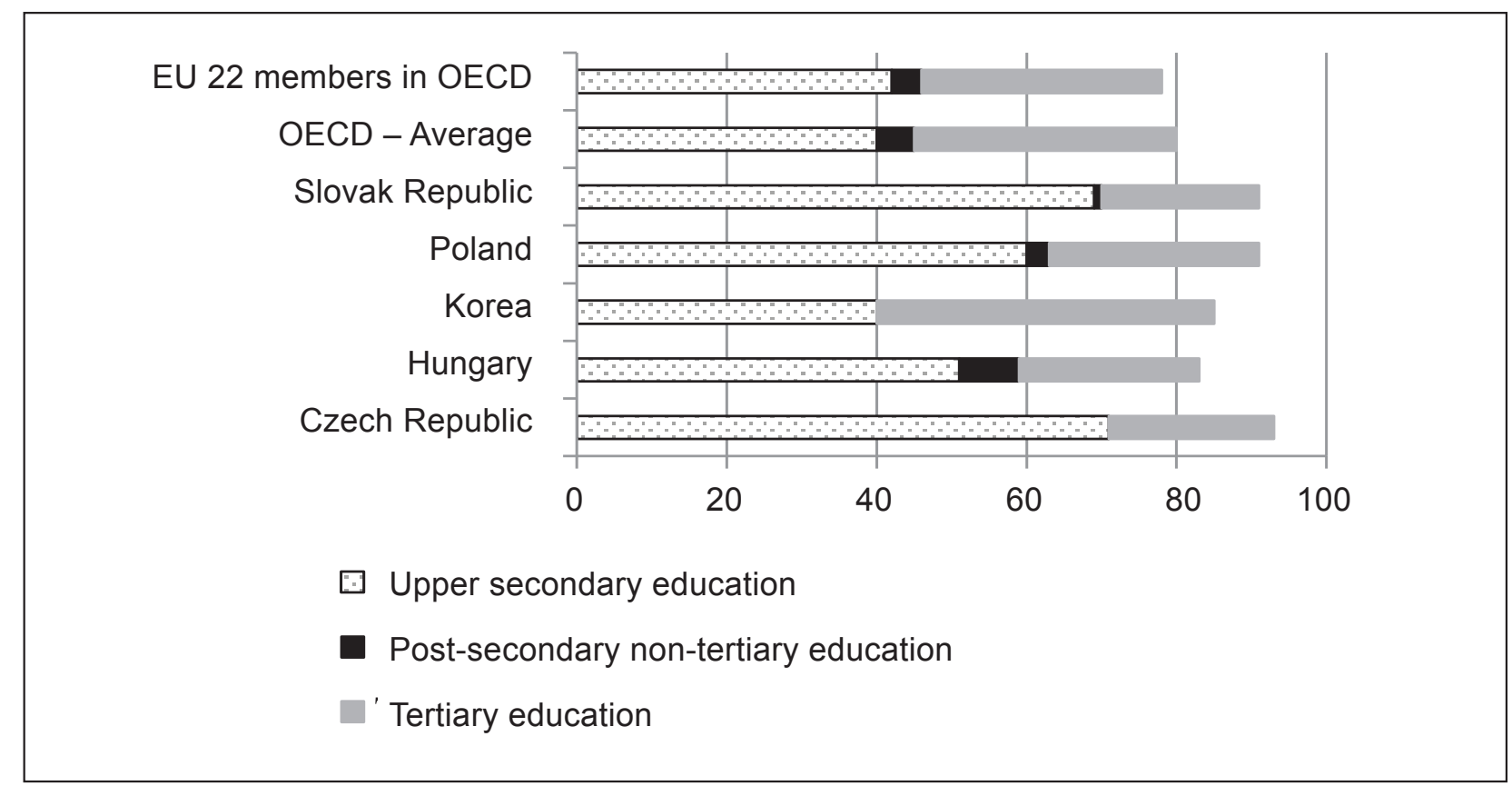

Source: authors, based on OECD Database (2017b)

A dramatic decline can be observed in the case of the Slovakian share of freshmen in the technical education between 2008 and 2015. However, the Slovakian rate was originally quite high in comparison to the V4 average. In Hungary and Poland, the share of freshmen has slightly increased in the technical education contrary to the decreasing overall number of tertiary education students. (See Figure 5)

South-Korean spending on tertiary education is among the highest; according to the OECD (2017c) database, South-Korea was the $4^{\text {th }}$ after the United States, Costa Rica and Chile with spending $2.3 \%$ of its GDP on tertiary education in 2013. This rate is lower by $0.9-1.2 \%$ in the V4 countries. Moreover, the student-teacher ratio in tertiary education is quite low in South-Korea. This rate is significantly higher in the V4 countries: in case of Poland or Czech Republic, the student-teacher ratio is at least twice as high as that of South-Korea. South-Korea was the $11^{\text {th }}$ in the PISA results in 2016, which is above the OECD average. Among V4 countries, Poland performs above the OECD average in the PISA test, while Czech Republic is around the average. Slovakia and Hungary perform below the average. Regarding PISA scores in mathematics of the other V4 countries, in 2015 Czech Republic ranked around the OECD average, while those of Hungary and Slovakia were not as good as the OECD average. (Table 1) The relevance and correctness of the PISA ranking is debated, it constitutes, however, strong marketing arguments for locations with above average results, where the Republic of Korea is also ranked. In the press release of Samsung at the opening of the fourth R\&D unit in Poland in 2013, in Cracow, Dae-Hyun Sim, VP and Head of Samsung R\&D Institute Poland pointed at the high level technical education and the conducive business environment behind their expansion. He regarded their Polish R\&D Institute mentioned above, which is employing 1000 mainly IT engineers, as "one of the biggest and fastest growing modern-technology R\&D centers in East-Central Europe" (samsung.com). The Polish example indicates that 
the V4 countries have a potential to improve their expertise to attract more Korean investments and move upward in the global value chain.

Figure 5 | Number of freshmen in higher education (thousand, left scale) and technical higher education institutions (\% of total freshmen, right scale)

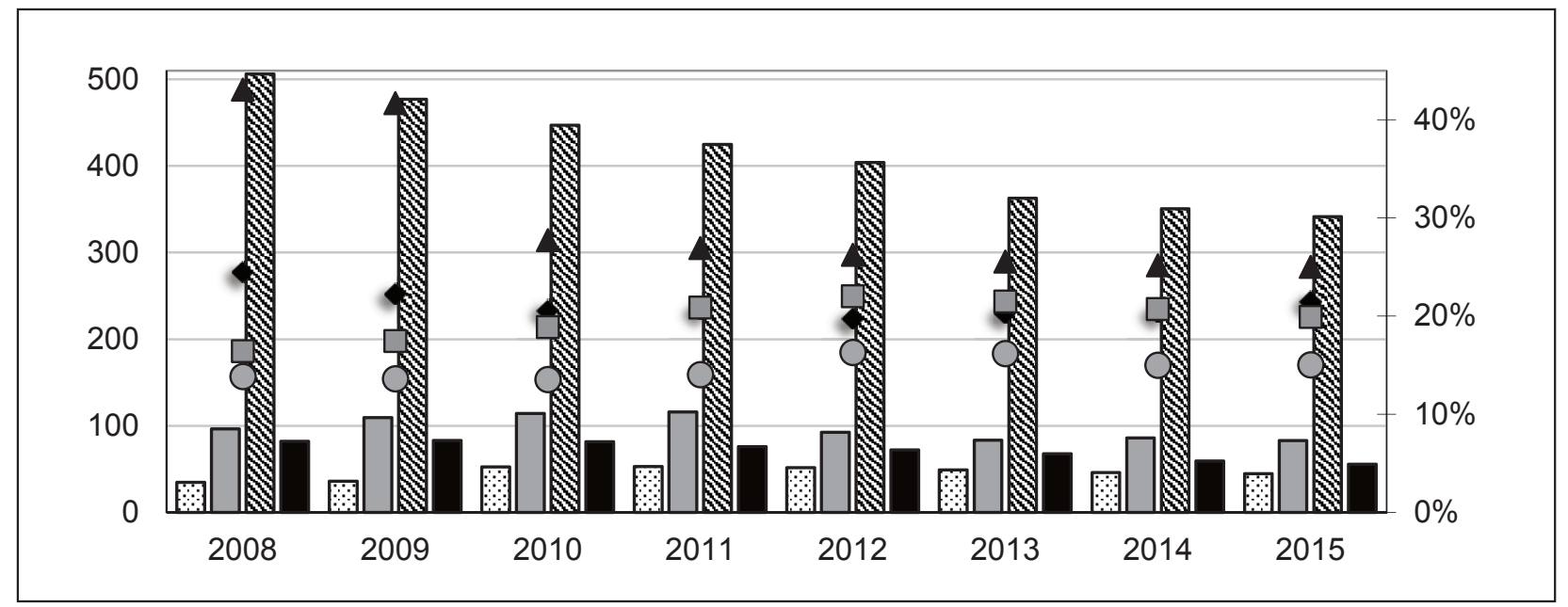

Sources: authors based on data of Statistical Office of the Slovak Republic (2017), Felvi.hu (2017), Central Statistical Office of Poland (2017) and Czech Statistical Office (2017).

Note: SK - Slovakia, HU - Hungary, PL - Poland, CZ - Czech Republic. The Czech data on share of polytechnic freshmen was not found. The $\mathrm{CZ}$ share of graduated polytechnic students was calculated as it follows: the number of students graduated in technical sciences divided by the total number of graduated students in Czech Republic.

Table 1 | Spending on tertiary education and student-teacher ratio in tertiary education in selected countries

\begin{tabular}{|l|c|c|c|c|c|}
\hline \multirow{2}{*}{$\begin{array}{l}\text { Country/Quality of } \\
\text { education }\end{array}$} & \multirow{2}{*}{$\begin{array}{c}\text { Education } \\
\text { spending } \\
\text { tertiary (\% of } \\
\text { GDP, 2013) }\end{array}$} & $\begin{array}{c}\text { Student- } \\
\text { teacher ratio } \\
\text { (tertiary, } \\
\mathbf{2 0 1 3 - 2 0 1 4 ) *}\end{array}$ & Science & Reading & Math \\
\cline { 5 - 6 } & 1.3 & 25.2 & 493 & 487 & 492 \\
\hline Czech Republic & 1.3 & 16.5 & 477 & 470 & 477 \\
\hline Hungary & 2.3 & 9 & 516 & 517 & 524 \\
\hline Korea & 1.4 & 19 & 501 & 506 & 504 \\
\hline Portugal & 1.4 & 11.1 & 501 & 498 & 492 \\
\hline Slovak Republic & 1.1 & 16.4 & 461 & 453 & 475 \\
\hline OECD - Average & 1.5 & $n / a$ & 493 & 493 & 490 \\
\hline EU 22 members in OECD & $1.4^{*}$ & 16.1 & $497^{*}$ & $495^{*}$ & $495^{*}$ \\
\hline
\end{tabular}

Source: authors, based on OECD Database (2017c), OECD (2016), * based on OECD Database (2017d) and Eurostat (2017) and UNESCO (2017). 


\subsection{V4 Labor Market Trends}

The year 2016 saw a significant change in the labor market situation. The V4 economies came close to their limits in employment. As Figure 6 represents it, the V4 employment ratios have reached or even exceeded the EU average. In the age group 15-64, the V4 ratios are between 65 and 72 percent. In this aspect, Czech Republic has the most intensively utilized workforce with the lowest labor reserves. The unemployment ratios have decreased significantly since the crisis years of 2009-2011, except in Slovakia. The number of jobseekers has been declining continuously in the region. Besides, the crisis years mobilized the competitive workforce to seek jobs in Western European labor markets. The job opportunities will not automatically move back to the home country. Although wages have been increasing in the V4 countries because of the labor shortage, there are 3-5 times higher wages in the highly developed EU labor markets, according to the Eurostat.

Figure 6 | Unemployment and employment ratio, age group 15-64, 2016Q3, \%

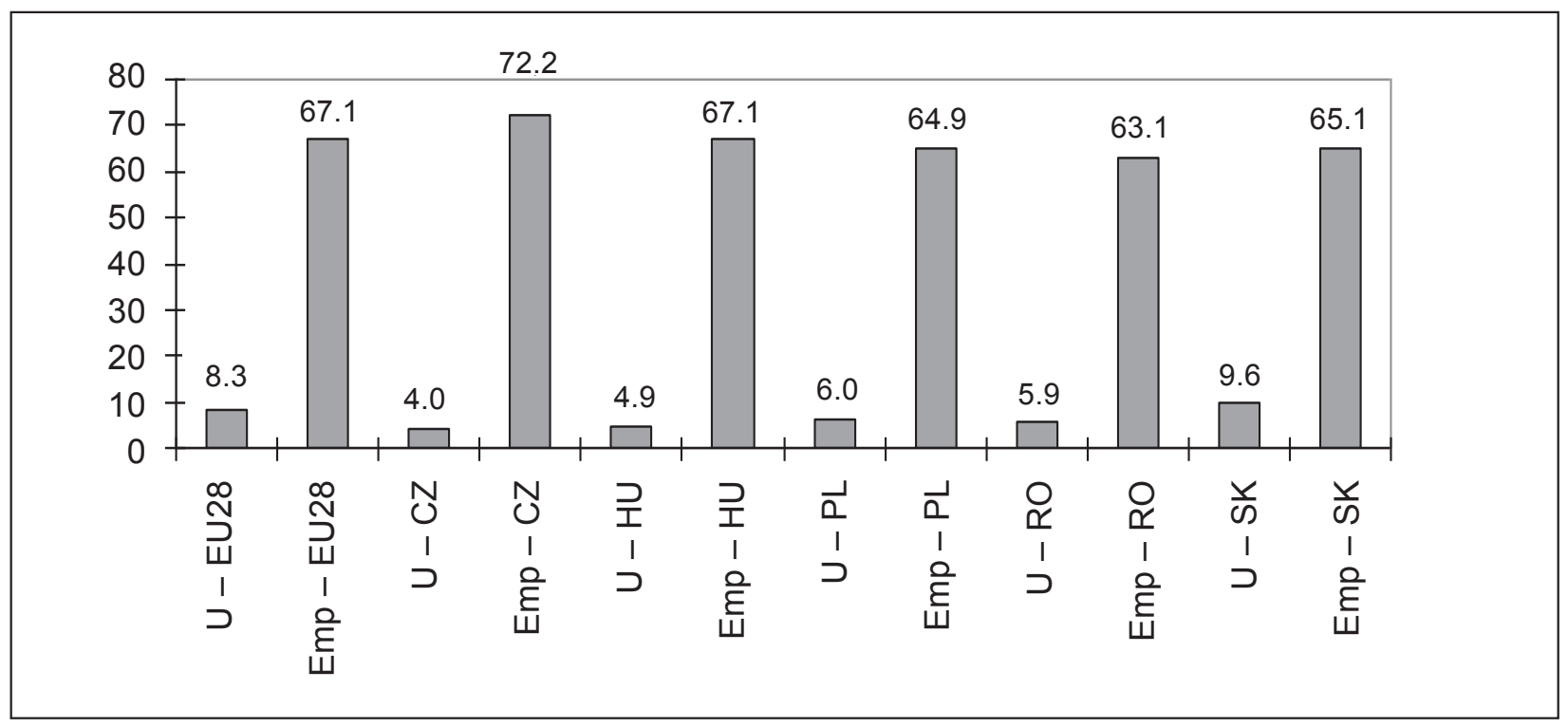

Source: authors, based on Eurostat (2017)

Note: $\mathrm{U}=$ unemployment ratio, Emp = employment ratio, SK - Slovakia, HU - Hungary, PL - Poland, CZ - Czech Republic, RO - Romania (Romania is included as there is an affiliated company of SEC Hungary)

Even though the general ratios of employment and unemployment might indicate labor reserves in a quantitative approach, in fact, the electronics industry demands specified and experienced workforce. Figure 7 represents the employment ratio of population with secondary, upper-secondary and tertiary education, in the age group of 15-64. This part of the active population can be taken into account as a potential workforce for Samsung and any other electronics company. The specified employment ratio is significantly above the general one in every V4 country. In the current SEC locations, it was $76 \%$ in Hungary, $74 \%$ in Poland and $72 \%$ in Slovakia. However, electronics demand mostly those who have specific education. In the aggregate statistics, the general 'technicians' and 'associate professionals' data is available. Analyzing the unemployment data of 2016, there were 5700 unemployed jobseekers in Hungary, 6400 in Slovakia, 23100 
in Poland, 7800 in Czech Republic and 6500 in Romania whose previous occupation was technician or associate professional. These numbers confirm that the region has limited labor capacities.

Figure 7 | Employment ratio of population with secondary, upper-secondary and tertiary education, age group 15-64, 2010Q1-2016Q3, \%

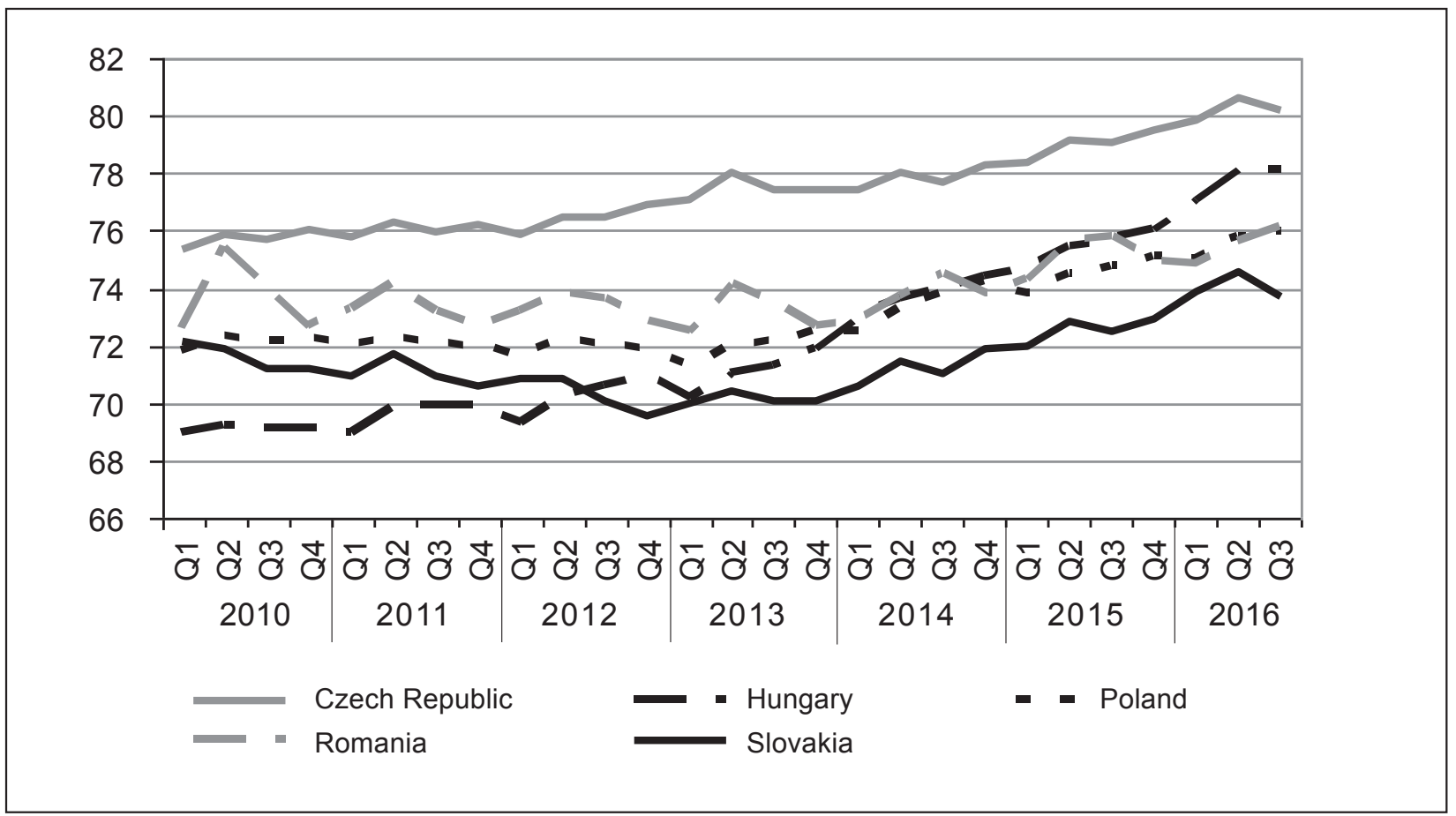

Source: Eurostat (2017), authors' calculation, (Romania is included as there is an affiliated company of SEC Hungary)

The employers have another chance to find workers if they can activate the inactive population. The volume of the hidden capacity can be identified since statistical offices have estimated the characteristics of inactive people. Figure 8 focuses on inactive population with upper secondary, post-secondary and tertiary education in the age group of 15-64. Only a few thousand people with acceptable qualifications to a manufacturing sector can be found in the inactive groups. Altogether, there are 10,450 people in the V4 + Romania region.

According to the overall inactive population's willingness to work only $6-18 \%$ of them can be expected to become active by financial or other incentives. (In the case of Hungary, the so called public work scheme includes approximately 200,000 active and employed people, but according to the HCSO and Ministry of Internal Affairs data, a few thousand of them would be acceptable in manufacturing, mostly for jobs with lower value added.) 
Figure 8 | Inactive population with upper secondary, post-secondary and tertiary education (age group 15-64, thousand persons), and ratio of overall inactive population willing to work (age group 15-64, \%, out of total inactive)

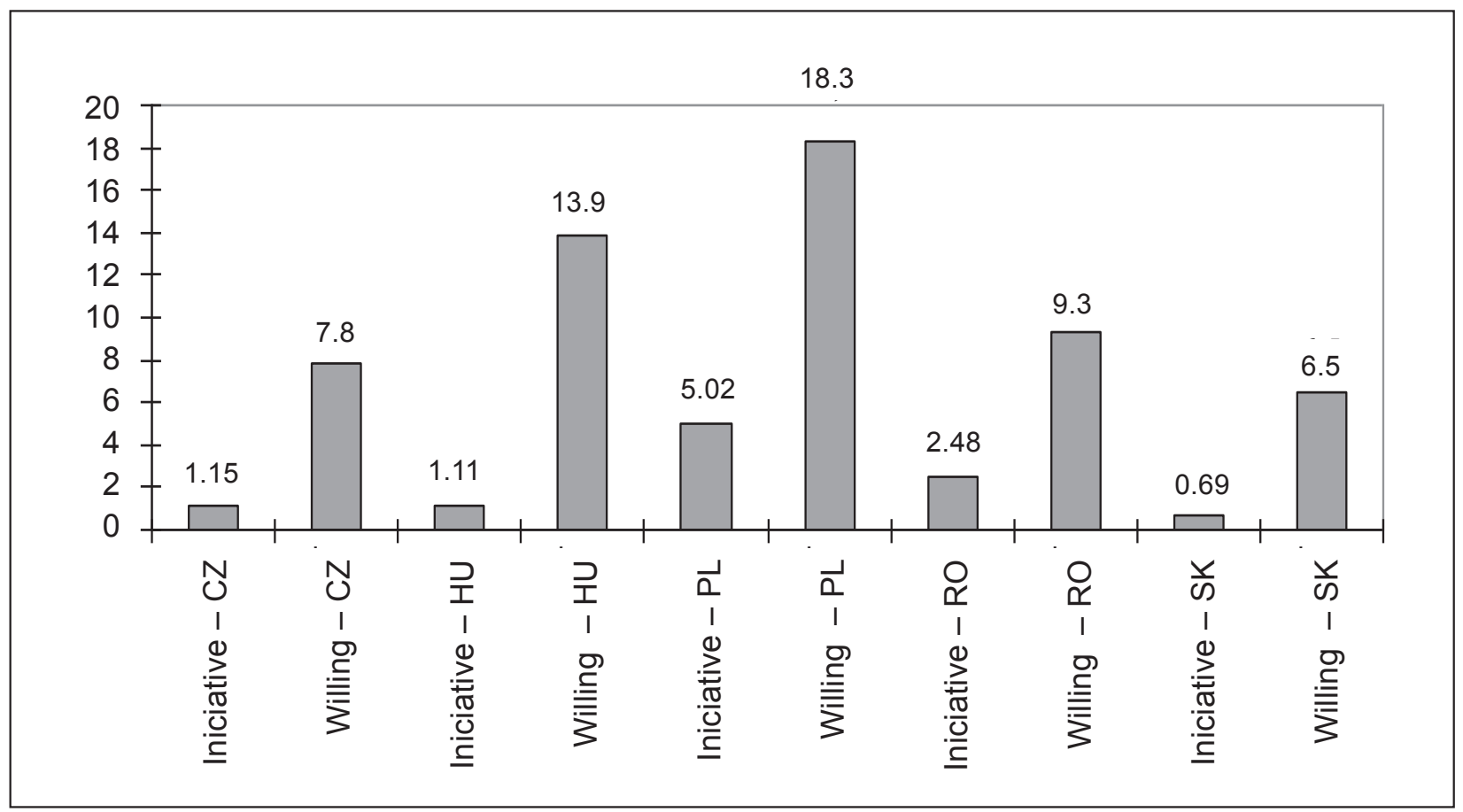

Source: authors' calculation based on Eurostat (2017) (Romania is included as there is an affiliated company of SEC Hungary)

Figure 9 | Impact of total factor productivity on economic growth, 2010-2016

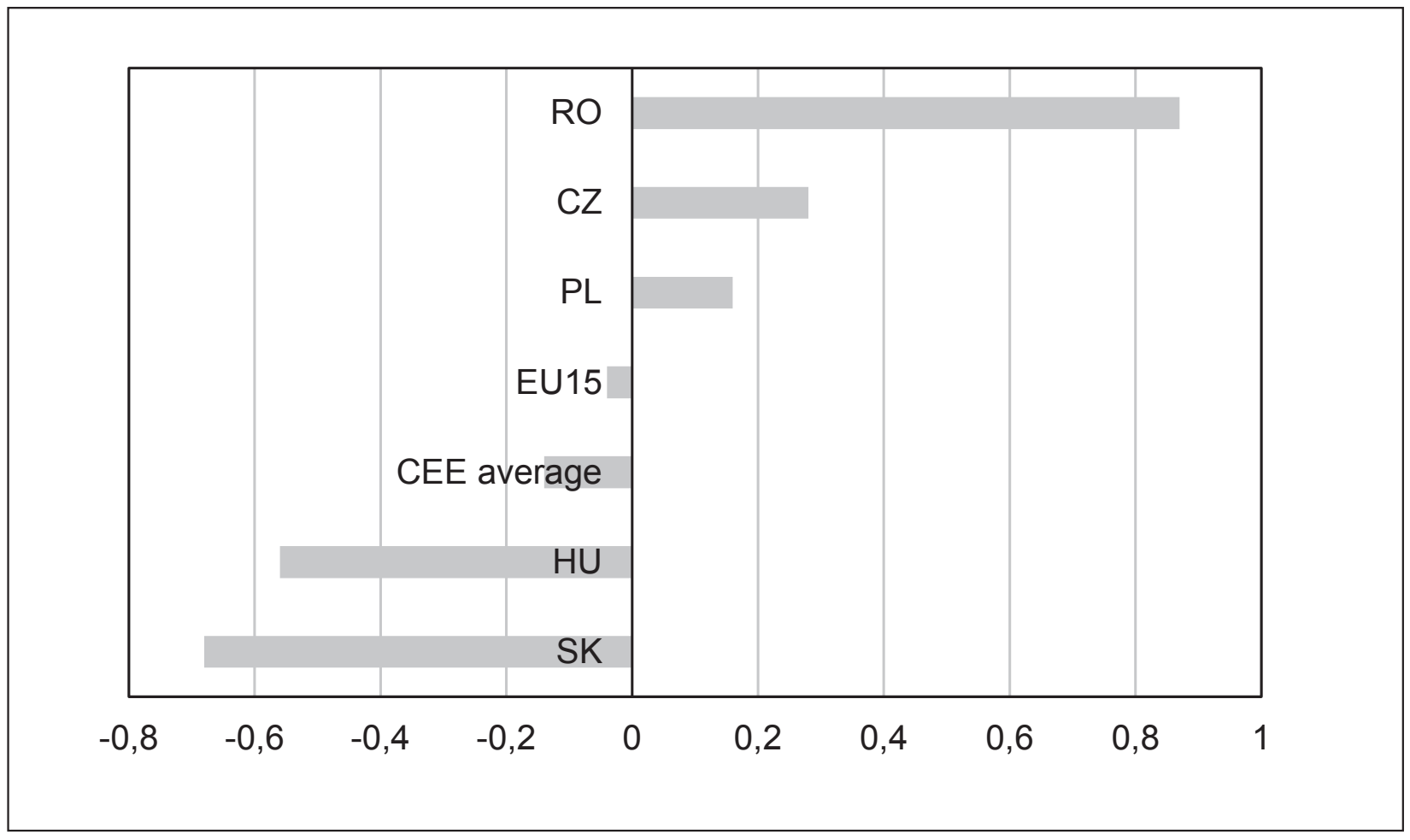

Source: Levenko et al. (2017, p. 19, table 5) 
The domestic sources of V4 labor markets were very limited in 2016 and 2017. The analyzed countries have a chance to extend their GVC activities if they can increase the productivity or the migrant labor supply. Productivity is not a real strength of Hungary and Slovakia - two main V4 locations of SEC - according to the total factor productivity data. Czech Republic and Poland are more competitive in this aspect. (See figure 9 and calculation by Halmai, 2014; Próchniak, 2016 and Levenko et al., 2017)

In every V4 economy, the immigrant labor supply is mostly fulfilled by Ukrainian workers, who are very much mobilized by the domestic economic and war situation, and, no less, by the wage differences. The net migration statistics indicates limited foreign labor resources. (Figure 10) In each year of the first half of the 2010s, thousands or tens of thousands of workers left the Polish and Romanian labor markets, not counterweighted by immigrants. The rest of the analyzed countries could gain a surplus of only a few thousand people in the overall migration per year.

\section{Figure 10 | Net migration, capita}

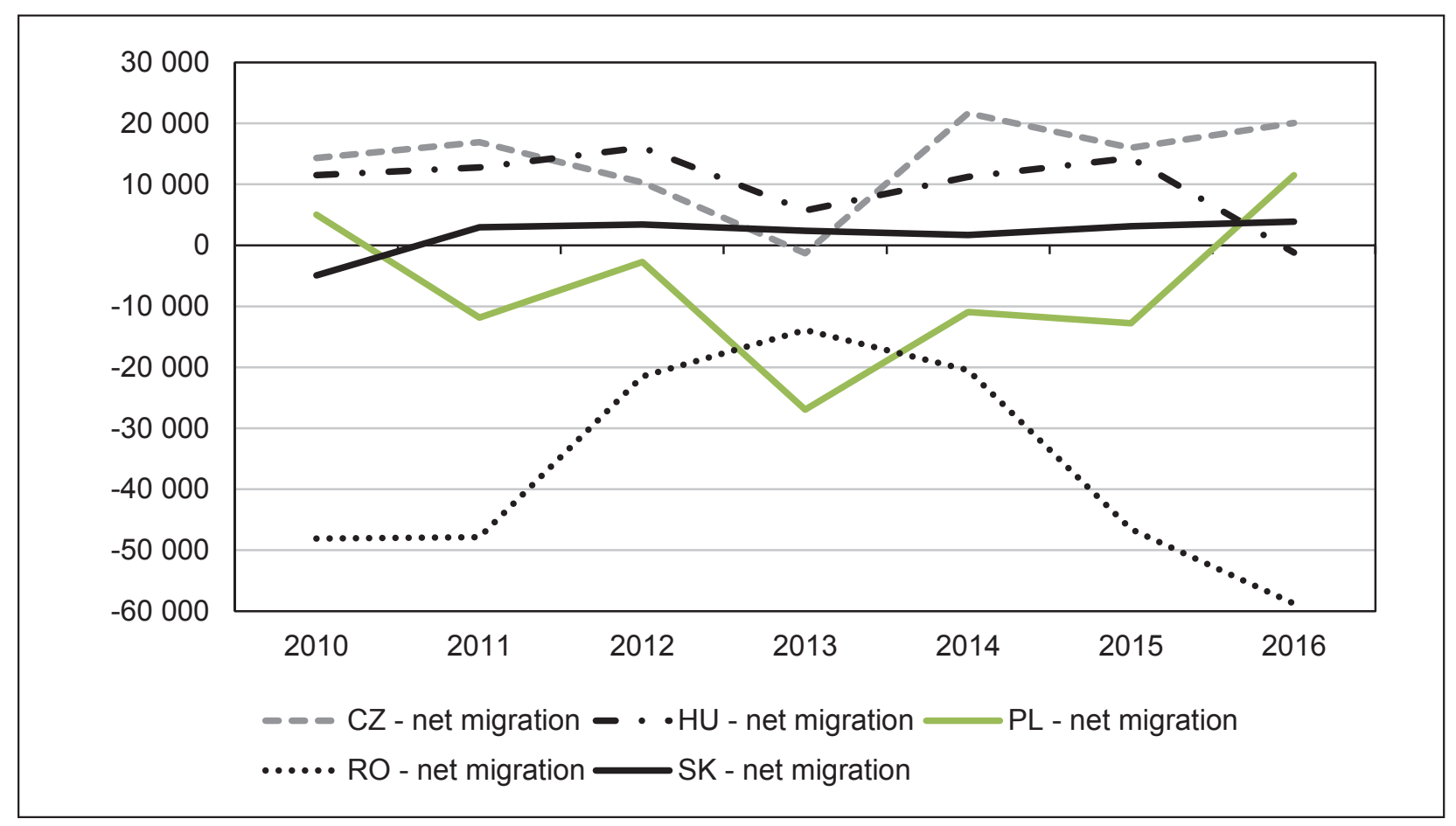

Source: authors' calculation based on Eurostat (2017)

The international wage differences also explain the limited labor resources of V4 countries. Figure 11 demonstrates that, in comparison to the V4 average wages, workers can earn 3 or 5 times more in the Western European labor markets, or even 8.6 times more in Switzerland. The only potential source of supply is the non-EU member Eastern European economies, which is limited. The average wage difference in the industry between the Ukrainian and the V4 labor markets was 4.5-5-fold in 2016 according to the national statistical offices. The Hungarian interview partners all confirmed that the sustainable operation, the expansion of the subsidiary and its larger suppliers has required for the last two years the employment of several hundreds of foreign workers. Citizens from two non-EU countries, Ukraine and Serbia are granted accelerated and simplified work permits by the national government, an advantage over the current Slovakian regulations. 


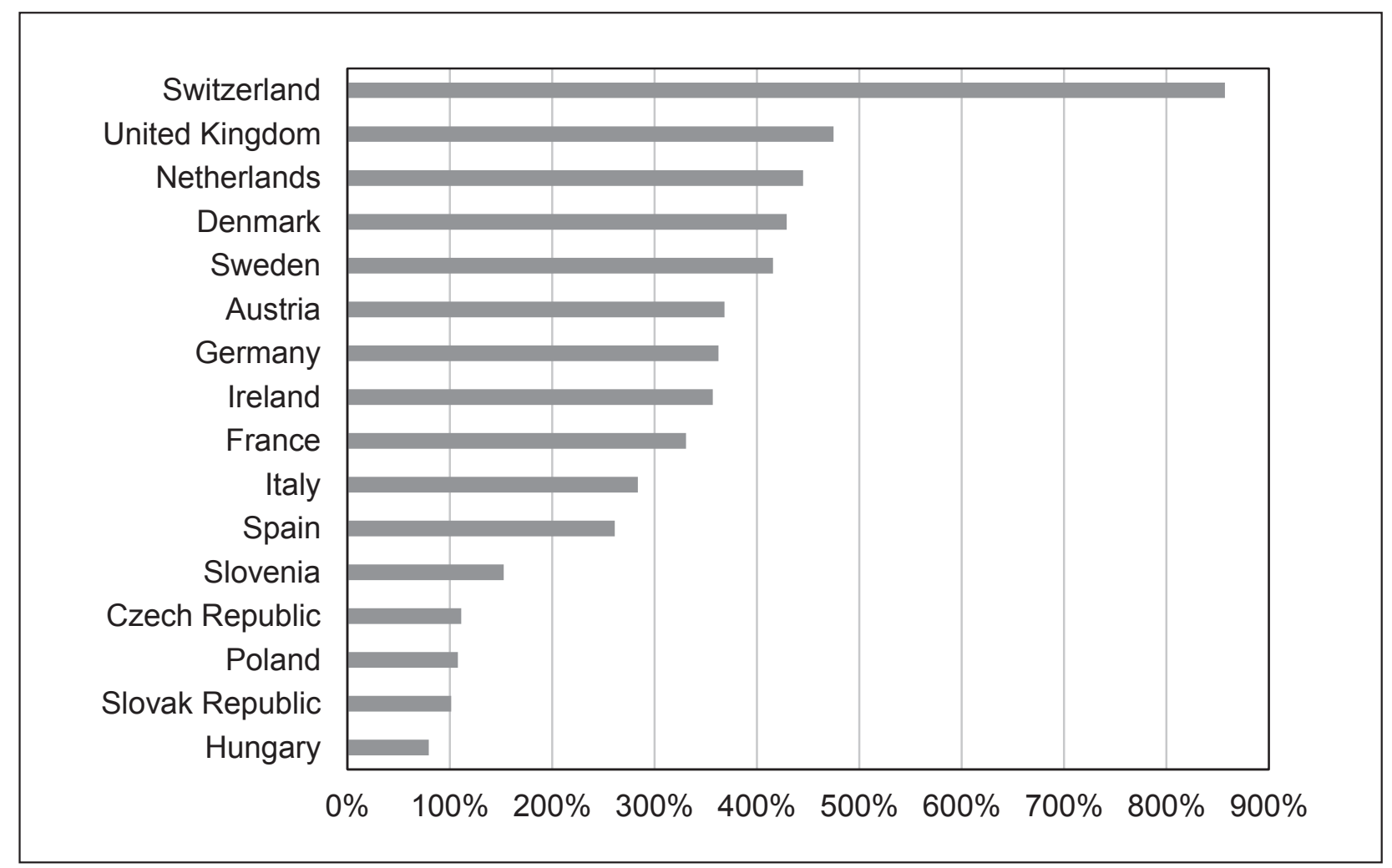

Source: authors' calculation based on OECD data (2018)

According to Slovakian press reports due to labor shortage in January 2018 Samsung Slovakia decided to close down its relatively new green field plant in Voderady, where LCD panels have been manufactured. Press reports claimed that long administrative procedures to employ foreign workers and the Slovakian government's unwillingness to change them stand behind the decision. Samsung's official announcement on the closure on $28^{\text {th }}$ January referred to consolidation of the activities and increasing efficiency (Reuters). Permanent workers will be offered a similar job in the Galanta plant.

\section{Conclusions}

The paper explored, through the case study of Samsung Electronics in the V4 countries, with a qualitative analysis of the development of SEC Hungary, the motives behind entering into the region and operating within the Samsung global value chain in the past almost 3 decades. It analyzed the role of location, state aid and expertise behind the development, confirming that all the three elements have had significant impact. Although the outstanding development is coupled with Samsung's overall innovative strategy and global market share gain in the TV production segment, a collaboration of a set of national and local actors also played an important role in SEC Hungary's positioning as Europe's largest and most modern TV manufacturing site with constantly increasing embeddedness, analyzed in the paper through the lens of the Global Production Network (GPN) framework.

Furthermore, opportunities were reviewed in upgrading in the Samsung value chain to enter higher value added activities both for the subsidiaries and their suppliers. As a theoretical support, the analysis is based on the GVC literature. The methodological 
pillar is the typology of the economic upgrading: product upgrading, process upgrading, functional development and intra-sectoral upgrading.

To sketch the corporate frame of the upgrading opportunities of V4 subsidiaries, the empirical analysis started with the innovation strategy of SEC. Samsung Electronics focuses on innovation and continuous improvement in R\&D. It was established, too, that SEC is not a first mover in innovation, rather a fast second, which is true, too, in the case of its internationalization strategy. The company has competitive advantage by using knowledge transfer among the production chains. Its main goal is to satisfy consumers' needs but for a lower price than its rivals. The research covered more extensively Samsung's activity in Hungary, relying on semi-structured interviews as well. Developments in the other V4 countries were introduced based on desktop research from primary and secondary sources. In the Samsung Electronics case study the Czech Republic plays a less significant role, as the group has only a Sales and Marketing subsidiary for the Czech Republic and Slovakia, but has no manufacturing or R\&D facilities in the country.

As locational elements and the possibility of state support within the EU grant similar possibilities for the V4 countries, the availability of expertise was discussed in more detail to uncover the abilities and limits for upgrading their position in the SEC GVC towards higher value added activities and innovation intensity.

The SEC case study confirms a special position of Poland, where the Korean TNC entered with an R\&D Center in 2000. Samsung had entered into Hungary ten years earlier with manufacturing activity within the value chain and has achieved product and process upgrading in this field with constant investments in the most advanced technology. The evolving functional upgrading has led to a greater independence of the Hungarian subsidiary. As a result of that its main local suppliers could join in the last 2 decades in the product adaptations and process-development tasks, allowing considerable knowledge transfer to the local firms. Classic base and applied research and development functions, however, have not been transferred to the SEC subsidiary by the head office; other Samsung divisions (Samsung Chemical in 2011, Samsung SDI in 2014) have up to now invested also into manufacturing facilities in Hungary. A further step towards innovation intensive activities could be fostered by the availability of an abundant number of highly-skilled engineers and technicians. Hungary and Slovakia currently underperform in functional literacy indicators in comparison to the OECD average, as well as those of South-Korea and the other two V4 countries. The decreasing and aging population does not help the V4 region to sustain the number of students in the tertiary technical education. All V4 countries show declining numbers in new enrollment to technical universities. Particularly it can be explained by the attractiveness of Western European universities and the free movement of students in the EU. To help the SEC subsidiaries and their suppliers in further upgrading their value chain position, strong focus is to be made on skill improvement in the secondary technical education and the attractiveness of tertiary engineering education.

Both quantitative and qualitative research concluded that the V4 labor markets are tightening, and unemployment level is low. The inactive workforce has a very limited number of appropriate technicians and professionals; it has a very low propensity to be active. As interviews, press reports confirmed, the V4 electronics industry needs to rely on foreign workers, mainly from Ukraine. Furthermore, total factor productivity indicates currently limited opportunities of Slovakia and Hungary in productivity development. 
This phenomenon does not support the objective to further upgrade in global value chains in the electronics industries of these countries. Economic policy should prioritize the development of education based on long term strategies, and with capable institutions to implement them in order to improve secondary and tertiary education in functional skills and technical education. Cooperative vocational training, scholarship programs financed by state or corporate actors could contribute to match the demand and supply of professionals needed for the electronics industry. Strong efforts are needed to retain the domestic skilled workforce, or to attract skilled foreign manpower. The labor shortage has started to impact on wages, but there are still four- or five-fold differences compared to the Western European levels. Emigration has an opportunity cost both in the economic and social sense, but further improvement of the wage level is needed to keep qualified engineers and skilled workers in the V4 countries.

Results of the Polish educational reforms introduced in 2000 show that catching up in skills and capabilities is possible within a relatively short period and are honoured by global TNCs, as the expansion of the SEC R\&D Center into 3 further university towns confirms.

\section{References}

Baldwin, R. E., \& Evenett S. J. (2012). Value Creation and Trade in 21st Century Manufacturing: What Policies for UK Manufacturing? In D. Greaway (Eds), The UK in a Global World. How can the UK focus on steps in global value chains that really add value? (pp. 71-128). London: London Centre for Economic Policy Research.

Baldwin, R. E. (2012). Global supply chains: Why they emerged, why they matter, and where they are going. CEPR Discussion Papers 9103.

Buckley, P. J. (2009). The impact of the global factory on economic development. Journal of World Business, 44(2), 131-143.

Business Insider (2013). History of Samsung. Retrieved August

22, 2017, from http://www.businessinsider.com/

history-of-samsung-2013-2\#now-check-out-a-gadget-not-made-by-samsung-16.

Central Statistical Office of Poland (2015). Higher education institutions and their finances.

Retrieved August 22, 2017, from http://stat.gov.pl/en/topics/education/education/highereducation-institutions-and-their-finances-in-2015,2,9.html.

Central Statistical Office of Poland (2017). Higher education institutions and their finances. Retrieved August 22, 2017, from http://stat.gov.pl/en/topics/education/education/highereducation-institutions-and-their-finances-in-2015,2,9.html.

Czech Statistical Office (2017). University education - first enrolled, graduates. Retrieved August 7, 2017, from https://vdb.czso.cz/vdbvo2/faces/en/index.jsf?page=vystup-objekt\&z=T\&f= TABULKA\&skupld=1167\&katalog=30848\&pvo=VZD12\&pvo=VZD12\&str=v66\#w=.

Eduline (2013). Íme a számok: legalább tízezerrel csökkent a felsőoktatásba jelentkezők száma. Retrieved August 7, 2017, from http://eduline.hu/felsooktatas/2013/3/13/ Ime_a_szamok_legalabb_tizezerrel_csokkent_a_IAFOKT.

Euromonitor International (2011). Poland to Overtake Italy and Germany as Europe's Biggest Producer of Major Appliances. Retrieved August 10, 2017, from https://blog.euromonitor. com/2011/08/poland-to-overtake-italy-and- germany-as-europes- biggest-producerof-major-appliances 
Eurostat (2017). Database. Retrieved July 22, 2017, from http://ec.europa.eu/eurostat.

Felvi.hu (2017). Felvételi ponthatárok, rangsorok. Retrieved July 5, 2017, from https://www. felvi.hu/felveteli/ponthatarok_rangsorok/elmult_evek/!ElmultEvek/elmult_evek. php?stat $=7 \& s 1=1 \& s 2=3 \& s 3=1 \& s t a \_k p t \_i d=8$.

Forbes (2017). The World' Biggest Public Companies, Samsung Electronics. Retrieved July 22, 2017, from http://www.forbes.com/companies/samsung-electronics/.

Dicken, P. (2015). Global Shift. Seventh Edition. Mapping the Changing Contours of the World Economy. New York: The Gulford Press.

Gereffi, G., \& Fernandez-Stark, K. (2011). Global Value Chain Analysis: A Primer. Center on Globalization, Governance \& Competitiveness (CGGC), Durham: Duke University.

Gereffi, G. (1999). International trade and industrial upgrading in the apparel commodity chain. Journal of International Economics, 48(1), 37-70.

Griliches, Z. (2000). R\&D, Education and Productivity, A retrospective. Cambridge: Harvard University Press.

Halmai, P. (2014). Krízis és növekedés az Európai Unióban. Európai modell, strukturális reformok. Budapest: Akadémiai Kiadó

Henderson, J., Dicken, P., Hess, M., Coe, N., \& Yeung, H. W. (2002). Global Production Networks and the analysis of economic development. Review of International Political Economy, 9(3), 436-464.

Humphrey, J., \& Schmitz, H. (2002). How Does Insertion in Global Value Chains Affect upgrading in Industrial Clusters? Regional Studies, 36(9), 1017-1027.

ICEG-CC (2015). Hungarian Multinationals in 2013 - A slow recovery after the crisis? Retrieved May 14, 2018, from http://ccsi.columbia.edu/files/2015/03/EMGP-Hungary-Report-2015covering-2013-FINAL.pdf.

Jung, S. C. (2014). The Analysis of Strategic Management of Samsung Electronics Company through the Generic Value Chain Model, International Journal of Software Engineering and Its Applications, 8(12), 133-142.

Lee, J. (2002). Education Policy in the Republic of Korea: Building Block or Stumbling Block? World Bank. Retrieved March 29, 2018, from http://siteresources.worldbank.org/WBI/Resources/ wbi37164.pdf.

Magasházi A., Szijártó N., \& Tétényi A. (2015). Integrated in global value chains by Korean-V4 participation. In M. Gress \& M. Grancay (Eds.), Mutual relations between the Republic of Korea and V4 countries in trade and investment: Conference proceedings International Scientific Conference and Workshop (pp. 156-177). Bratislava: Vydavatelstvo Ekonóm.

Levenko et al. (2017). Total Factor Productivity growth in Central and Eastern Europe before, during and after the global financial crisis. Eurosüsteem, Working Paper Series 8/2017. Retrieved May 14 2018, from https://www.eestipank.ee/en/publications/series/ working-papers.

OECD (2016). PISA 2015, Results in Focus. OECD.

OECD Database (2017a). Educational attainment of 25-64 year-olds, by programme orientation. Retrieved June 5, 2017, from http://stats.oecd.org/Index.aspx?datasetcode=EAG_NEAC.

OECD Database (2017b). Educational attainment and labour-force status, Retrieved June 5, 2017, from http://stats.oecd.org/Index.aspx?datasetcode=EAG_NEAC.

OECD Database (2017c). Education spending, tertiary, \% of GDP (2013). Retrieved June 5, 2017, from https://data.oecd.org/eduresource/education-spending.htm\#indicator-chart. 
OECD Database (2017d). Teacher staff, tertiary, number (2014). Retrieved June 12, 2017, from https://data.oecd.org/eduresource/teaching-staff.htm\#indicator-chart.

Parilli, M. D. (2014). The Competition of Clusters in Globalized Markets. Implications for Regional Development. London and New York: Routledge. Taylor \& Francis Group.

Pavlinek, P. \& Zizalova, P. (2014). Linkages and spill overs in global production networks: firmlevel analysis of the Czech automotive industry. Journal of Economic Geography 16(2), 331-363.

Porter, M. C. (1990). The competitive advantage of nations. New York: Free Press.

Próchniak, M. (2016). Changes in Total Factor Productivity. In M.A. Weresa (Ed.): Poland Competitiveness Report 2016 (pp.141-148). Warsaw: SGH Warsaw School of Economics.

Rodrik, D. (1997). The 'paradoxes' of the successful state. European Economic Review, 41(4-5), 411-442

Samsung (2017). Research and development. Retrieved July 12, 2017, from http://www. samsung.com/us/aboutsamsung/samsung_electronics/business_area/rd_page/.

Sass, M., \& Szalavetz, A. (2012). Industrial policy options for catching-up GVC actors: the Visegrad countries in the post-crisis GVC environment. Working paper, Hungarian Academy of Sciences.

Schlossstein, D. F. (2010). Institutional Change in Upstream Innovation Governance: The Case of Korea. Frankfurt am Main: Peter Lang GmbH.

Simonin, D. (2014). International Strategy: The Strategy of Samsung Group. Working Paper, University of Geneva.

Statistical Office of the Slovak Republic (2017). Newly admitted students of Institutions. Retrieved June 12, 2017, from http://www.statistics.sk/pls/elisw/objekt. send?uic $=2473 \&$ m_sso $=2 \&$ m_so $=31 \& \mathrm{ic}=49$.

Tchorek, K. (2011). Samsung: Proud tradition of maths proves a strong draw, The Financial Times, November 1.

Trapp, R. (2016). Better Management, Education and Training Needed to Close the Productivity Gap. Forbes Online. Retrieved March 29, 2018, from https://www.forbes.com/sites/ rogertrapp/2016/02/26/better-management-education-and-training-needed-to-closethe-productivity-gap/\#3fe7335e5473.

UNESCO (2017). Pupil-teacher ratio by level of education. Retrieved June 12, 2017, from http://data.uis.unesco.org/?queryid=180.

WIOD (2016). Database from 2000 to 2014. Retrieved June 12, 2017, from http://www.wiod.org/ gvc.

World Bank (2017). Poland's Education System: Leading in Europe. Retrieved June 12, 2017, from http://www.worldbank.org/en/news/opinion/2016/01/22/ polands-education-system-leading-in-europe.

WTEC (1997). WTEC Report on the Korean electronics industry. World Technologies and Services Papers, Retrieved March 22, 2017, from http://www.wtec.org/loyola/kei/welcome.htm.

Yeung, H. W. (2016). Strategic Coupling. East Asian Industrial Transformation in the New Global Economy. Ithaca: US. Cornell University Press. 


\section{Authors}

\section{Viktória Endrődi-Kovács}

Assistant professor

Corvinus University of Budapest

Budapest, Hungary

viktoria.kovacs3@uni-corvinus.hu

\section{Gábor Kutasi}

Associate professor

Corvinus University of Budapest

Researcher of the National Bank of Hungary

Budapest, Hungary

gabor.kutasi@uni-corvinus.hu

\section{Anikó Magasházi}

Researcher

Institute of Advanced Studies, Kőszeg

Kőszeg, Hungary

aniko.magashazi@iask.hu 